\title{
EFFECT OF DIETARY PHOSPHORUS AND ZINC LEVELS ON HEMATOCRIT VALUE, PLASMA MINERAL CONTENT AND PLASMA ALKALINE PHOSPHATASE ACTIVITY OF FINGERLING RAINBOW TROUT, Oncorhynchus mykiss
}

\author{
M. S. A. Sarker* and S. Satoh ${ }^{1}$ \\ School of Agriculture and Rural Development, Bangladesh Open University \\ Gazipur-1705, Bangladesh
}

\begin{abstract}
A laboratory based $2 \times 2$ factorial experiment was conducted to investigate the effects of dietary phosphorus and zinc levels on hematocrit value, plasma alkaline phosphatase activity and plasma mineral contents of rainbow trout fingerling for 21 weeks. Two levels of phosphorus (19 and $30 \mathrm{mg} / \mathrm{g}$ ) and two levels of zinc ( 55 and $100 \mu \mathrm{g} / \mathrm{g}$ ) in the dry diets were tested. Duplicate tanks of 30 rainbow trout (average weight $1.56 \pm 0.24 \mathrm{~g}$ ) per $60 \mathrm{~L}$ glass tank were fed experimental diets three times a day to satiation level in 15 to $24^{\circ} \mathrm{C}$ water temperature. Zinc supplementation in the practical diets significantly increased the hematocrit value, plasma alkaline phosphatase activity and plasma zinc contents in rainbow trout fingerling. On the other hand, addition of phosphorus did not show any significant difference among the treatments. The result of the present study demonstrated that additional zinc significantly $(\mathrm{P}<0.05)$ influenced the hematocrit value, plasma alkaline phosphatase activity and plasma zinc contents in rainbow trout. Hence, it can be concluded that zinc supplementation is necessary in fingerling rainbow trout feed. Further studies in this area with different size and age of rainbow trout are needed broadly.
\end{abstract}

Key words : Hematocrit, Plasma mineral, Plasma alkaline phosphatase, Rainbow trout

\section{INTRODUCTION}

Rainbow trout, which belongs to the family Salmonidae, is endemic to western North American and eastern Asia and exists in a number of distinctive ecological forms and sub forms, which differ in morphology, behavior and life history traits. This species was originally taxonomically linked with the Atlantic or Eurasian trouts of the genus Salmo. The natural geographical distribution of rainbow trout includes freshwater systems along the eastern Pacific Ocean, mainly west of the Rocky Mountains, from the northwest Mexico (including extreme northern Baja California) to the Kuskokwim River in

\footnotetext{
${ }^{1}$ Laboratory of Fish Nutrition, Department of Marine Biosciences, Tokyo University of Marine Science and Technology, Minato, Tokyo-108-8477, Japan

* Corresponding E-mail :- sarkeralam@yahoo.com
} 
southwestern Alaska. In Asia, rainbow trout are most abundant on the Kamchatka Peninsula. Rainbow trout have been introduced widely outside their natural range in suitable habit throughout North America and other parts of the world, such as South America, Europe, Southern Asia, Japan, Africa and Oceania (Groot, 1996; Scott and Crossman, 1975).

In the natural environment rainbow trout feed on various invertebrates including plankton, larger crustaceans, fish insects, snails, and leeches. Nutritional requirements of rainbow trout have been well studied (NRC, 1993). Rainbow trout is by far the most widely farmed trout in the world and one of the few species of fish that may be regarded as truly domesticated.

Like in other animals, $\mathrm{P}$ is an essential nutrient for fish, being a major constituent of skeletal tissues, nucleic acids, DNA and RNA, energy transport compounds like ATP, and of phospholipids in cell membranes (Lall, 1991). Dietary phosphorus (P) is essential for optimal growth and metabolism of fish. It is the most important mineral needed by fish, since its requirement and functions are superior to that of any other mineral element (NRC, 1993; Satoh et al., 2002).

Information on the metabolism, excretion and utilization of dietary $\mathrm{P}$ in fish is limited (Lall, 1991). However, the necessity of $\mathrm{P}$ supplementation in a fish meal-based diet has been reported for the post juvenile stage (Masumoto, 2002). Fish meal is the source of most dietary $\mathrm{P}$ in fish diets, wherein it exists as hydroxyapatite and/or tricalcium phosphate (TCP). Due to its structural complexity, P and Ca from TCP have been reported to be less available to some fish species (Takamtus et al., 1975; Shitanda et al., 1979; Watanabe et al., 1980) as a result of which, large amount of P are excreted in feces, leading to wastage, and environmental pollution. On the other hand, inorganic phosphorus from sodium phosphate is highly available to all fish.

Zinc $(\mathrm{Zn})$ is required in the diet as it is more efficiently absorbed than the waterborne $\mathrm{Zn}$ (NRC, 1993). It is essential for growth, development and maintenance of healthy bones (Yamaguchi, 1998), and functions as a cofactor of several enzymes and an integral part of about 20 metalloenzymes such as alkaline phosphates (ALP), alcohol dehydrogenase and carbonic anhydrase (Hambidge et al., 1986; Watanabe et al., 1997). Moreover, Zn deficiency affects the digestibility of protein and carbohydrate because of the reduced activity of carboxypeptidase (Ogino and Yang, 1978). There may be interaction effect of $\mathrm{Zn}$ and $\mathrm{P}$ on hematocrit value, plasma alkaline phosphates activity and plasma mineral contents of fingerling rainbow trout.

Therefore, the present study aimed to investigate the effects of dietary phosphorus and zinc levels and their interaction on hematocrit value, plasma alkaline phosphates activity and plasma mineral contents of fingerling rainbow trout. 


\section{MATERIALS AND METHODS}

\section{Experimental diets and design}

Practical diets were formulated to contain 19 and $30 \mathrm{~g} / \mathrm{kg} \mathrm{P}$ employing monocalcium phosphate, and 54 and $100 \mathrm{~g} / \mathrm{kg} \mathrm{Zn}$ using inorganic zinc sulphate (Table 1). The diets were labeled according to factors (P and $\mathrm{Zn}$ ) and as P0Z0, P0Zl, PlZ0 and PlZl. The experimental diets were formulated to be isocaloric and isonitrogenous. The carbohydrate sources and binders were wheat flour and pregelatinized starch, and the lipid source was pollock liver oil and soybean oil. The formulation and composition of experimental diets are presented in Table 1 . The experiment was conducted in a $2 \times 2$ factorial design with the factors 'dietary phosphorus level' and 'supplemental Zn level'.

Table 1. Formulation and composition of the experimental diets

\begin{tabular}{|c|c|c|c|c|}
\hline \multirow[t]{2}{*}{ Ingredients (\%) } & \multicolumn{4}{|c|}{ Diets } \\
\hline & P0Z0 & P0Zl & $\mathrm{PlZ0}$ & $\mathrm{PlZl}$ \\
\hline Jack mackerel meal & 57 & 57 & 57 & 57 \\
\hline Wheat flour & 20 & 20 & 20 & 20 \\
\hline Pregelatinized starch & 5 & 5 & 5 & 5 \\
\hline Pollock liver oil & 4 & 4 & 4 & 4 \\
\hline Soybean oil & 5 & 5 & 5 & 5 \\
\hline Mineral premixutrea & 0 & 1 & 0 & 1 \\
\hline Zn free mineral mixture ${ }^{b}$ & 0 & 1 & 0 & 1 \\
\hline $\mathrm{Ca}\left(\mathrm{H}_{2} \mathrm{PO}_{4}\right)_{2}$ & 0 & 0 & 4 & 4 \\
\hline Vitamin premizturec & 1.5 & 1.5 & 1.5 & 1.5 \\
\hline Choline chloride & 0.5 & 0.5 & 0.5 & 0.5 \\
\hline Vitamin E (50\%) & 0.1 & 0.1 & 0.1 & 0.1 \\
\hline Cellulose & 5.9 & 5.9 & 5.9 & 5.9 \\
\hline
\end{tabular}

a Mineral premixtur (\%) - $\mathrm{NaCl} 5.0, \mathrm{Mg} \mathrm{SO}_{4} .7 \mathrm{H}_{2} \mathrm{O} 74.5, \mathrm{FeC}_{6} \mathrm{H}_{5} \mathrm{O}_{7} .7 \mathrm{H}_{2} \mathrm{O}$ 12.5, Trace element mix. ${ }^{*}$ 5.0, Cellulose 3.0

$\mathrm{a}^{*}(\%)-\mathrm{ZnSO}_{4} .7 \mathrm{H}_{2} \mathrm{O} 553, \mathrm{MnSO}_{4} .5 \mathrm{H}_{2} \mathrm{O}$ 162, $\mathrm{CuSO}_{4} .5 \mathrm{H}_{2} \mathrm{O} 31, \mathrm{AlCl}_{3} \cdot 6 \mathrm{H}_{2} \mathrm{O}$ 10, CoCl.6 $\mathrm{H}_{2} \mathrm{O} 1, \mathrm{KIO}_{3} 3$, Cellulose 986

c Vitamin mix (\%)- Thiamine hydrochloride 6, Riboflavin 10, Pyridoxine hydrochloride 4, Cyanocobalamin 0.01, Ascorbic acid 500, Niacin 40, Ca-pantothenate, 10, Inositol 200, Biotin 0.6, Folic acid 1.5, $p$-aminobenzoic, Vitamin $\mathrm{K}_{3}$ 5, Vitamin A acetate $4000 \mathrm{IU}$, Vitamin $\mathrm{D}_{3} 4000 \mathrm{IU}$

The minerals mixture used in this study was the modified form of Ogino salt mixture (Ogino et al., 1980). The diets were pelleted using the labortory pelletizer (AEZ12M, Higaga-Seikakusho, Kobe, Japan), dried in a vacuum freeze-drier (RLE-206, Kyowa Vacuum Tech., Saitama, Japan), and stored at $4^{\circ} \mathrm{C}$ until used. The proximate composition and minerals contents of the experimental diets used in this study are shown in Table 2 and Table 3, respectively. The diets ware prepared with $57 \%$ fish meal (FM) as the sole 
protein source. Ingredients used in the test diets were selected taking into consideration the amino acid balance of the whole protein sources (Watanabe et al., 1993).

Table 2. Proximate composition of the experimental diets (dry matter basis)

\begin{tabular}{l|c|c|c|c}
\hline \multirow{2}{*}{\multicolumn{1}{c|}{ Parameters }} & \multicolumn{4}{c}{ Diets } \\
\cline { 2 - 5 } & P0Z0 & P0Z1 & PlZ0 & PlZl \\
\hline Moisture (\%) & 4.5 & 4.5 & 3.0 & 4.5 \\
Crude ash (\%) & 11.1 & 10.8 & 13.7 & 13.6 \\
Crude protein (\%) & 44.9 & 44.7 & 45.5 & 45.2 \\
Crude lipid (\%) & 16.6 & 16.7 & 16.6 & 16.9 \\
Gross energy (kcal/g) & 5.2 & 5.2 & 5.0 & 5.0 \\
\hline
\end{tabular}

Table 3. Mineral contents of the experimental diets (dry matter basis)

\begin{tabular}{l|c|c|c|c}
\hline \multirow{2}{*}{ Macro elements } & \multicolumn{4}{|c}{ Diets } \\
\cline { 2 - 5 } & P0Z0 & P0Zl & PlZ0 & PlZl \\
\hline P (mg/g) & 19.14 & 19.49 & 30.30 & 30.09 \\
$\mathrm{Ca}(\mathrm{mg} / \mathrm{g})$ & 28.03 & 30.19 & 34.76 & 35.20 \\
$\mathrm{Mg}(\mathrm{mg} / \mathrm{g})$ & 3.00 & 3.05 & 3.00 & 2.97 \\
$\mathrm{Na}(\mathrm{mg} / \mathrm{g})$ & 3.86 & 3.41 & 3.58 & 3.82 \\
$\mathrm{~K}(\mathrm{mg} / \mathrm{g})$ & 4.71 & 3.75 & 4.32 & 4.50 \\
Trace elements & & & & \\
$\mathrm{Zn}(\mu \mathrm{g} / \mathrm{g})$ & 54.54 & 103.24 & 55.85 & 96.07 \\
$\mathrm{Mn}(\mu \mathrm{g} / \mathrm{g})$ & 40.44 & 40.71 & 41.18 & 40.62 \\
$\mathrm{Fe}(\mu \mathrm{g} / \mathrm{g})$ & 345.54 & 341.90 & 352.17 & 348.24 \\
$\mathrm{Cu}(\mu \mathrm{g} / \mathrm{g})$ & 7.04 & 7.05 & 10.63 & 8.35 \\
\hline
\end{tabular}

\section{Fish rearing and feeding methods}

Eyed egg of rainbow trout were obtained from Fuji Trout Farm of Shizuoka Prefecture Fisheries Experiment Station and hatched under laboratory conditions at the Tokyo University of Marine Science and Technology in the year 2005. Fish with an average body weight of $1.56 \pm 0.24 \mathrm{~g}$ were randomly selected from stock and distributed into $60 \mathrm{~L}$ tanks at a density of 30 fish per tank. Triplicate groups were assigned to each experimental diet and the feeding was conducted for 21 weeks. The fish were hand fed three times per day, six days a week to apparent satiation level. The tanks had a continuous water supply at a rate of $0.6-1.01 / \mathrm{min}$ and the temperature was 15 to $24^{\circ} \mathrm{C}$.

\section{Sampling and analytical methods}

The fish were starved for $24 \mathrm{~h}$ before being individually weighed at the initial day and every 21 days of the experimental period after being anesthetized with ethylene glycol 
monophenyl ether (300 ppm). At the same time 5 fish were randomly sampled from each tank and stored at $-20^{\circ} \mathrm{C}$ for analyses.

Proximate composition and chemical analyses of the diets and fish whole body samples were made in three replicates. Proximate analysis of the samples were performed as follows: moisture contents was measured gravimetrically, crude ash contents was determined by incinerating a known amount of sample in an electric muffle furnace (Yamato, FA-21) at $600^{\circ} \mathrm{C}$ for 8 hours, crude protein was analyzed using the Kjeltec Auto Sampler System 1035/38 (Netherland), and crude lipid was measured by following the method of Folch et al. (1957). Samples for minerals were digested in nitric acid using the MLS-1200 Mega Microwave Digestion System (Italy), cooled in flowing water for 30 minutes, and diluted with de-ionized water to the required volume. Concentration of each element was measured by a Polarized Zeeman Atomic Absorption Spectrophotometer (Hitachi Z-5010, Tokyo, Japan) except for phosphorus which was analyzed by a visible light spectrophotometry (Shimadzu, UV 265 FW, Kyoto, Japan) at $750 \mathrm{~nm}$.

\section{Hematocrit (Hct)}

Hct level was determined by centrifugation of the heparinized blood samples in microhematocrit tubes at $5000 \mathrm{rpm}$ for $5 \mathrm{~min}$ using a High-Speed Micro centrifuge MC-150 (Tomy, Japan).

\section{Enzyme assay (Plasma alkaline phosphates)}

Plasma sample were obtained from heparinized blood samples of the fish at the end of the experiment. The alkaline phosphate (ALP) activity of the antocoagulated blood plasma was determined using the test pack by the Abbott Vision System (Abbott Laboratories, IL, USA). The ALP of the sample catalyses the magnesium-activated base hydrolysis of p-nitro-phenyl phosphate producing nitrophenolate and the reaction is measured based on the increase in absorbance at $418 \mathrm{~nm}$. The rate of hydrolysis is directly proportional to the activity of the enzyme (Abbott Laboratories 1989).

\section{Statistical analyses}

Statistical analyses were performed using one-way and two-way ANOVA with SYSTAT 8.0 software (SPSS Inc., 1998). Differences between treatments were evaluated by Tukey's test. The level of significance was set at $\mathrm{P}<0.05$ for all tests.

\section{RESULTS AND DISCUSSION}

Weight gain of the fish did not show any significant difference among treatments of both $\mathrm{P}$ and $\mathrm{Zn}$ throughout the culture period. Also SGR, FCR and TGC were not significantly affected by the treatment (Table 4). The results of growth performance and feed utilization suggest that different levels of both $\mathrm{P}$ and $\mathrm{Zn}$ had no influence on the feed intake and growth performance of fish. In addition, the results represent the stated parameters not to ie potential and appropriate indices to assess $\mathrm{P}$ and $\mathrm{Zn}$ level 
differences. Similar results were obtained by Hardy and Shearer (1985); Li and Robinson (1996); Apines et al. (2001).

Table 4. Growth and feed performance of the experimental diets for 21 weeks

\begin{tabular}{lccccccc}
\hline Diet group & Weight gain & SGR $^{1} \% /$ day $)$ & FCR $^{2}$ & TGC $^{3}$ & Condition factor \\
\hline P0Z0 & $73.62^{\mathrm{a}}$ & $2.62^{\mathrm{a}}$ & $0.97^{\mathrm{a}}$ & $0.001125^{\mathrm{a}}$ & $1.161^{\mathrm{a}}$ \\
P0Zl & $72.61^{\mathrm{a}}$ & $2.62^{\mathrm{a}}$ & $0.96^{\mathrm{a}}$ & $0.001118^{\mathrm{a}}$ & $1.153^{\mathrm{a}}$ \\
PIZ0 & $62.88^{\mathrm{b}}$ & $2.52^{\mathrm{b}}$ & $1.01^{\mathrm{b}}$ & $0.001047^{\mathrm{b}}$ & $1.162^{\mathrm{a}}$ \\
PIZl & $59.54^{\mathrm{b}}$ & $2.48^{\mathrm{b}}$ & $1.02^{\mathrm{b}}$ & $0.001021^{\mathrm{b}}$ & $1.125^{\mathrm{a}}$ \\
P & $<0.05$ & $<0.05$ & $<0.05$ & $<0.05$ & NS \\
Z & $\mathrm{NS}$ & $\mathrm{NS}$ & $\mathrm{NS}$ & NS & NS \\
$\mathrm{P} \times \mathrm{Z}$ & $\mathrm{NS}$ & $\mathrm{NS}$ & $<0.05$ & $\mathrm{NS}$ & NS \\
\hline
\end{tabular}

${ }^{1}$ Specific growth rate; ${ }^{2}$ Feed conversion ratio. ${ }^{3}$ Thermal-unit growth coefficient

* Values in the same column not sharing a common superscript letter are significantly different $(\mathrm{P}<0.05)$

Feed conversion in the present study also did not differ among the treatments, which indicates that the tested sources had no influence on feed intake and growth performance of the fish. Conversely, growth and feed consumption were significantly influenced by the dietary Zn levels in abalone (Tan and Mai, 2001).

Carcass proximate composition of rainbow trout at start and end of the experiment presented in the Table 5 revealed influence of $\mathrm{Zn}$ supplementation on crude ash though not remarkable while P supplementation showed significant difference on whole body crude ash contents. This is in agreement in our previous study (Sarker et al. 2009).

Table 5. Proximate carcass composition of fish at start $(n=30)$ and end $(n=12)$ of the experiment fed experimental diets

\begin{tabular}{l|ccccc}
\hline Initial/Diet group & Moisture (\%) & Crude ash (\%) & Crude protein (\%) & Crude lipid (\%) \\
\hline Initial & 76.36 & 2.63 & 15.36 & 5.88 \\
P0Z0 & 67.37 & $1.97 \mathrm{~b}$ & 16.46 & 14.35 \\
P0Zl & 67.33 & $2.03 \mathrm{ab}$ & 16.26 & 14.33 \\
PlZ0 & 68.58 & $2.36^{\mathrm{a}}$ & 16.28 & 12.71 \\
PlZl & 68.58 & $2.17 \mathrm{ab}$ & 16.31 & 13.22 \\
P level & NS & $<0.05$ & NS & NS \\
Zn level & NS & NS & NS & NS \\
P level $\times$ Zn level & NS & NS & NS & NS \\
\hline
\end{tabular}

Values in the same column not sharing a common superscript letter are significantly different $(\mathrm{P}<0.05)$

Hematocrit level of the fish at the end of the experiment is presented in Table 6. It was in the control group and it increased slightly $(\mathrm{P}>0.05)$ with the additional $\mathrm{Zn}$. On the other 
hand, the increase was not very prominent in the $\mathrm{P}$ supplement group. Higher fish hematocrit level in the $\mathrm{Zn}$ supplemental groups compared to the control group in this study indicates better health condition achieved by $\mathrm{Zn}$ supplemented groups as well as influencing the availability of trace minerals. This is in agreement with the earlier findings of rainbow trout and red sea bream (Apines-Amar et al., 2004; Sarker et al., 2005, 2007).

Table 6. Hematocrit value $(n=12)$ and plasma alkaline phosphate activities $(n=10$ of rainbow trout at the end of the experiment)

\begin{tabular}{l|c|c}
\hline \multicolumn{1}{c}{ Diet group } & Hematocrit value (\%) & Plasma alkaline phosphate activities (U/L) \\
\hline P0Z0 & $35^{\mathrm{b}}$ & $114.93^{\mathrm{b}}$ \\
P0Zl & $41^{\mathrm{a}}$ & $122.67^{\mathrm{a}}$ \\
PlZ0 & $34^{\mathrm{b}}$ & $116.52^{\mathrm{b}}$ \\
PlZl & $40^{\mathrm{a}}$ & $121.35^{\mathrm{a}}$ \\
P level & $\mathrm{NS}$ & $\mathrm{NS}$ \\
Zn level & $<0.05$ & $<0.05$ \\
P level $\times$ Zn level & $\mathrm{NS}$ & $\mathrm{NS}$ \\
\hline
\end{tabular}

Values in the same column not sharing a common superscript letter are significantly different $(\mathrm{P}<0.05)$. NS: Not significant

Supplementation of both $\mathrm{P}$ and $\mathrm{Zn}$ in the practical diet of rainbow trout did not show any significant difference on plasma $\mathrm{P}, \mathrm{Ca}, \mathrm{Mg}, \mathrm{Na}, \mathrm{K}, \mathrm{Fe}, \mathrm{Cu}$ and $\mathrm{Mn}$ (Table 7). On the country, addition of $\mathrm{Zn}$ in the practical diet significantly increased plasma $\mathrm{Zn}$ contents of rainbow trout (Fig. 1). This result indicates that additional $\mathrm{Zn}$ deposits in the plasma tissue and plasma is the indicator of $\mathrm{Zn}$ status of fish. David et al. 1982 reported that plasma Zn levels were positively correlated with dietary Zn intake.

Table 7. Plasma mineral contents of rainbow trout at the end of the experiment $(n=12)$

\begin{tabular}{l|c|c|c|c|c|c|c|c}
\hline \multicolumn{1}{c|}{ Diet group } & $\begin{array}{c}\mathrm{P} \\
(\mathrm{mg} / \mathrm{g})\end{array}$ & $\begin{array}{c}\mathrm{Ca} \\
(\mathrm{mg} / \mathrm{g})\end{array}$ & $\begin{array}{c}\mathrm{Mg} \\
(\mathrm{mg} / \mathrm{g})\end{array}$ & $\begin{array}{c}\mathrm{Na} \\
(\mathrm{mg} / \mathrm{g})\end{array}$ & $\begin{array}{c}\mathrm{K} \\
(\mathrm{mg} / \mathrm{g})\end{array}$ & $\begin{array}{c}\mathrm{Fe} \\
(\mu \mathrm{g} / \mathrm{g})\end{array}$ & $\begin{array}{c}\mathrm{Cu} \\
(\mu \mathrm{g} / \mathrm{g})\end{array}$ & $\begin{array}{c}\mathrm{Mn} \\
(\mu \mathrm{g} / \mathrm{g})\end{array}$ \\
\hline P0Z0 & 0.52 & 0.10 & 0.04 & 2.71 & 0.08 & 1.50 & 0.74 & 0.07 \\
P0Zl & 0.50 & 0.10 & 0.04 & 2.71 & 0.08 & 1.46 & 0.70 & 0.09 \\
PlZl & 0.46 & 0.10 & 0.04 & 2.72 & 0.08 & 1.79 & 0.88 & 0.09 \\
PlZl & 0.46 & 0.10 & 0.04 & 2.71 & 0.07 & 1.41 & 0.66 & 0.14 \\
P level & NS & NS & NS & NS & NS & NS & NS & NS \\
Zn level & NS & NS & NS & NS & NS & NS & NS & NS \\
P level $\times$ Zn level & NS & NS & NS & NS & NS & NS & NS & NS \\
\hline
\end{tabular}

NS : Not significant

The plasma alkaline phosphates activity was significantly higher in the $\mathrm{Zn}$ supplemented group compared to the control (Table 6). Several indicators such as serum levels (Turner et al. 1978), enzyme activities (Kfoury et al., 1968; Huber and Gershoff, 1973), whole body (Wekell et al., 1986) and bone levels (Huber and Gershoff, 1970) have been used to 
quantify Zn status in animals. Alkaline phosphates (ALP), a Zn-requiring enzyme is considered as a sensitive indicator of Zn levels in animals. The ALP activity in plasma of rainbow trout in the present study increased with the elevation of dietary $\mathrm{Zn}$ indicating that its concentration in the diet affected the enzyme level. This is in agreement with previous studies (Apines et al., 2001; Tan and Mai, 2001).

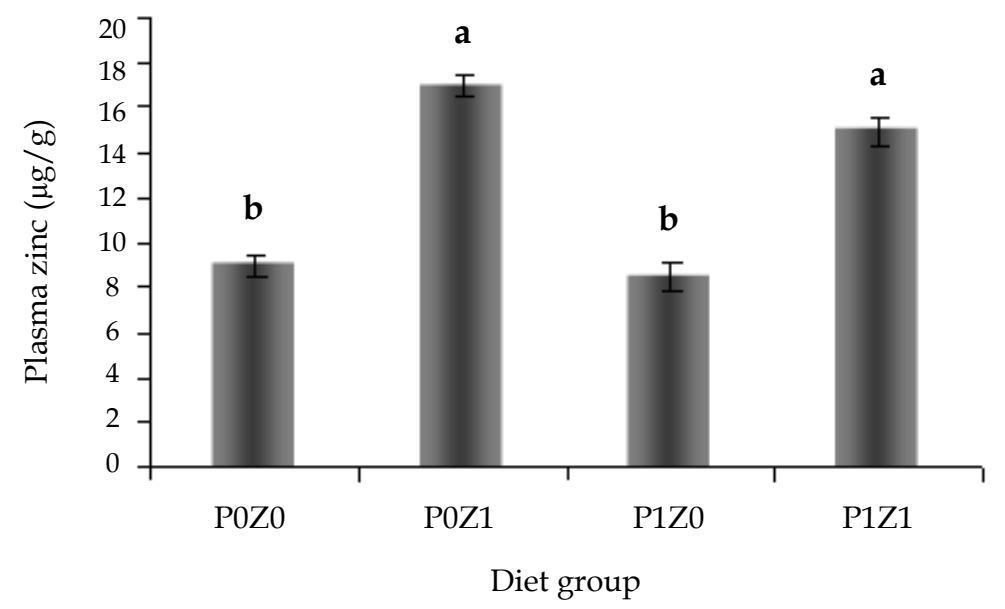

Fig. 1. Effect of dietary $\mathrm{P}$ and $\mathrm{Zn}$ levels on plazma zinc contents of rainbow trout at the end of the experiment $(n=12)$ fed the experimental diets for 21 weeks

The overall results of the present study demonstrated that additional zinc significantly influenced the hematocrit value, plasma alkaline phosphates activity and plasma zinc contents in rainbow trout. Hence it can be concluded form the study that zinc supplementation is necessary in fingerling rainbow trout feed and $\mathrm{P}$ supplementation is not needed. Thus further study in this area with different sized and aged rainbow trout will corroborate these findings.

\section{ACKNOWLEDGEMENTS}

The authors express their gratitude to the Japanese Ministry of Education, Culture, Sports, Science and Technology (MEXT) for the scholarship grant extended to Md. Shah Alam Sarker. We also thank to the Okutama Branch of the Tokyo Fisheries Experimental Station for providing the eyed-egg rainbow trout. This study was partly supported by the Grants-in-Aid for Scientific research of MEXT and the Grant of the Fisheries Agency of Japan.

\section{REFERENCES}

Apines-Amar, M. J. S., Satoh, S., Capang, C. M. A., Kiron, V., Watanabe, T. and Aoki, T. 2004. Amino acid chelate: a better source of $\mathrm{Zn}, \mathrm{Mn}$, and $\mathrm{Cu}$ for rainbow trout, Oncorhynchus mykiss, fingerlings. Aquaculture, 240: 345-358. 
Apines, M. J., Satoh, S., Kiron, V., Watanabe, T., Nasu, N. and Fugita, S. 2001. Bioavailability of amino acid chelated and glass emaded zinc to rainbow trout, Oncorhynchus mykiss, fingerlings. Aquacult. Nutri., 7: 221-228.

David, K., Cowey, C. B. and Adron, J. W. 1982. Effects of dietary copper and copper: zinc ratio on rainbow trout Salmo gairdneri. Aquaculture, 27: 111-119.

Folch, J., Lees, M. and Stanley, G. H. S. 1957. A simple method for isolation and purification of total liquid from animal tissues. J. Biol. Chem., 226: 45-63.

Groot, C. 1996. Salmonid life histories. In: Principles of salmonid culture. W. Pennel and B.A. Barton (eds). Elseiver, Amsterdam, pp. 97-230.

Hambidge., K. M., Casey, C. E. and Krebs, N. S. 1986. Zinc. In: Trace Element in Human and Animal Nutrition, Vol. 2. (5th ed). Mertz, W. (ed). Academic Press, San Diego, pp. 1-137.

Hardy, R. W. and Shearer, K. D. 1985. Effect of dietary calcium phosphate and zinc supplementation on whole body zinc concentration of rainbow trout (Lalmo gairdneri). Can. J. Fish. Aquat. Sci., 42: 181-184.

Huber, A. M. and Gershoff, S. N. 1970. Effects of dietary zinc and calcium on the retention and distribution of zinc in rats fed semipurified diets. J. Nutr., 100: 949-954.

Huber, A. M. and Gershoff, S. N. 1973. Effects of dietary zinc on zinc enzymes in the rat. J. Nutr., 103: 1175-1181.

Kfoury, G. A., Reinhold, J. G. and Simonian, S. J. 1968. Enzyme activities in tissues of zinc-deficient rats. J. Nutr., 95: 102-110.

Lall, S. P. 1991. Digestibility, metabolism and excretion of dietary phosphorus in fish. In: Nutritional Strategies and Aquaculture Waste. Cowey, C. B and Cho, C. Y. (eds). Proceedings of the First International Symposium on Nutritional Strategies in Management of Aquaculture Waste. University of Guelph, Guelph, pp. 21-35.

Li, M. H and Robinson, E. H. 1996. Comparison of chelated zinc and zinc sulfate as zinc sources for growth and bone mineralization of channel catfish (Ictlurus punctatus) fed practical diets. Aquaculture, 146: 237-243.

Masumoto, T. 2002 Yellowtail, Seriola quinqueradiata. In: Nutrient Requirements and Feeding of Finfish for Aquaculture. Webster C. D. and Lim, C. (eds). CAB International. pp. 131-146.

NRC (National Research Council). 1993. Nutrient Requirements of Fish. National Academy Press, Washington DC. USA.

Ogino, C. 1980. Requirements of carp and rainbow trout for essential amino acids. Nippon Suisan Gakkaishi, 46: 171-174.

Ogino, C. and G. Y. Yang. 1978. Requirement of rainbow trout for dietary zinc. Bull. Japan. Soc. Sci. Fish., 44: 1015-1018.

Sarker, M. S. A., Satoh, S. and Kiron, V. 2005. Supplementation of citric acid and amino acid-chelate trace element to develop environment-friendly feed for red sea bream, Pagrus major, Aquaculture, 248: 3-11.

Sarker, M. S. A., Satoh, S., Kiron, V. 2007. Inclusion of citric acid and.or amino acid-chelated trace element in alternate plant protein source diets affects growth and excretion of nitrogen and phosphorus in red sea bream, Pagrus major, Aquaculture, 262: 436-443.

Sarker, M. S. A., Satoh, S., Satoh, K., Yamamoto, Y. amd Kiron, V. 2009. Effects of dietary phosphorus supplementation on growth and excretion of nitrogen and phosphorus by growing yellowtail, Seriola quinqueradiata, Aquacult. Sci., 57(2): 279-284. 
Satoh, S., Takanezawa, M., Akimoto, A., Kiron, V. and Watanabe, T. 2002. Changes of phosphorus absorption from several feed ingredients in rainbow trout during growing stages of extrusion of soybean meal. Fish. Sci., 68: 325-331.

Scoot, W. B. and Croosman, E. J. 1975. Freshwater fishes of Canada. Fisheries Research Board of Canada, Ottawa. 966 p., R. and Ukita, M. 1979. Effect of phosphorus supplement to commercial diet on growth, feed efficiency, chemical component of serum and body with carp. Suisanzoshoku, 27: 26-32 (in Japanese).

SPSS Inc. 1998. SYSTAT Statistics, Version 8.0. SPSS Inc., Chicago, IL.

Takamatsu, C., Endoh, E., Hasegawa, T. and Suzuki, T. 1975. Effect of phosphate supplemented diet on growth of carp. Suisanzoshoku, 23: 55-60 (in Japanese).

Tan, B. and Mai, K. 2001. Zinc methionine and zinc sulfate as sources of dietary zinc for juvenile abalone, Haliotis discus hannai Ino. Aquaculture, 192: 67-84.

Turner, W. E., Carter, R. J., Bailey, G. G., Smith, W. B., Stroud, P. E. and Bayse, D. D. 1978. Serum zinc and copper levels in the National Health and Nutrition Examination Survey. Clin. Chem., 24: 1028-1029.

Watanabe, T., Murakami, A., Tekeuchi, L., Nos, T. and Ogino, C. 1980. Requirement of chum salmon held in freshwater for dietary phosphorus. Nippon Suisan Gakkaishi, 46: 361-367.

Watanabe, T., Pongmaneerat, J., Satoh, S. and Takeuchi, T. 1993. Replacement of fish meal by alternative protein sources in rainbow trout diets. Nippon Suisan Gakkaishi, 59: 1573-1579.

Watanabe, T., Verakunpiriya, V., Watanabe, K., Kiron, V. and Satoh, S. 1997. Feeding of rainbow trout with non-fish meal diets. Fish. Sci., 63: 258-266.

Wekell, J. C., Sheare, K. D. and, Gauglitz, E. J. Jr. 1986. Zinc supplementation of trout diets: tissue indicators of body zinc status. Prog. Fish. Cult., 48: 205-212.

Yamaguchi, M. 1998. Role of zinc in bone formation and bone resorption. J. Trace Elem. Exp. Med., 11: 119-135. 